\title{
AFFIRMATIVE ACTION UNTUK PENINGKATAN KESETARAAN BAGI KAUM DISABILITAS TUNARUNGU DALAM PEMENUHAN HAK MENIKMATI ACARA TELEVISI
}

Oleh:

Ni MadeAri Yuliartini Griadhi

\begin{abstract}
ABSTRAK
Disabilitas merupakan suatu ketidakmampuan tubuh dalam melakukan suatu aktifitas atau kegiatan tertentu sebagaimana orang normal pada umumnya yang disebabkan oleh kondisi ketidakmampuan dalam hal fisiologis, psikologis dan kelainan struktur atau fungsi anatomi. Ketika penyandang disabilitas berhadapan dengan hambatan maka hal itu akan menyulitkan mereka dalam berpartisipasi penuh dan efektif dalam kehidupan bermasyarakat berdasarkan kesamaan hak. Pengembangan bahasa isyarat bagi yang berkebutuhan khusus yaitu penyandang disabilitas sangat dibutuhkan dalam pengembangan dan pembinaan bahasa di Indonesia. Kekurangan ini tentunya memberikan hambatan serta menyulitkan penyandang disabilitas salah satunya dalam menikmati berita maupun hiburan pada siaran televisi.

Undang-UndangNomor 32 Tahun 2002 tentang Penyiaran menjamin bahwa hak memperoleh informasi adalah hak mutlak bagi setiap warga negara tanpa memandang kelompok. Jaminan ini harusnya juga diberikan kepada mereka yang memiliki kemampuan yang berbeda atau kaum disabilitas seperti tuna rungu. Pasal 39 ayat(3) UU Penyiaran No.32 Tahun 2002 menyatakan jaminan akan hak informasi dengan ketersediaan penerjamahan. Akan tetapi pasal dalam UU tersebut tidak tegas mewajibkan serta tidak adanya pengaturan sanksi bilamana tidak menerapkannya dengan baik terhadap kepastian pemenuhan secara maksimal bagi kaum disabilitas dalam menikmati siaran televisi.

Berdasarkanpemaparantersebut di atas, makadapatdirumuskanpermasalahansebagaiberikut : 1. Pengaturan bagi kaum disabilitas dalam memperoleh informasi.

2. Urgensi perlindungan serta Affirmative Action terkait kepastian dalam pemenuhan hak menikmati acara televisi bagi kaum disabilitas.

UU telah memberikan jaminan kepada penyandang disabilitas untuk mendapatkan informasi dan berkomunikasi melalui media yang mudah diakses; dan menggunakan dan memperoleh fasilitas informasi dan komunikasi berupa bahasa isyarat, braille, dan komunikasi augmentatif dalam interaksi resmi, serta mewajibkan Pemerintah serta Pemerintah Daerah utk menjaminnya.UU Penyiaran didalamnya belum secara tegas mengatur mengenai kewajiban stasiun televisi untuk menyediakan akses untuk kaum disabilitas tuna rungu untuk menikmati semua acara di televisi sangat urgen untuk memberikan pengaturan yang lebih menjamin pemenuhan hak menikmati acara televisi bagi kaum disabilitas tuna rungu dengan menentukan suatu Affirmative Action yang mewajibkan bagi stasiun TV untuk menyertakan Bahasa Isyarat dalam setiap siarannya.
\end{abstract}

Kata Kunci: Affirmative Action, Disabilitas, PemenuhanHak.

\section{PENDAHULUAN}

\subsection{Latar Belakang}

Affirmative action pada dasarnya adalah suatu kebijakan yang diskriminatif, walaupun dipandang termasuk genre diskriminasi yang positif karena sifatnya hanya sementara demi membuka kesempatan bagi kelompok masyarakat tertentu meraih peluang yang sama sebagaimana telah dinikmati oleh kelompok masyarakat lainnya. Dunia ekonomi dan pendidikan adalah 
lapangan affirmative action yang banyakdipakai. ${ }^{1}$ DalamhaliniadalahAffirmative action untuk Peningkatan Kesetaraan bagi Kaum DisabilitasTuna rungu dalam Pemenuhan Hak Menikmati Acara Televisi.

Dalam Undang-Undang Nomor 8 Tahun 2016 tentang Penyandang Disabilitas selanjutnya disebut UU PenyandangDisabilitas, yang dimaksud dengan penyandang disabilitas adalah setiap orang yang mengalami keterbatasanfisik, intelektual, mental dan atau sensorik dalam jangka waktu lama yang dalam berinteraksi dengan lingkungan dapat mengalami hambatan dan kesulitan untuk berpartisipasi secara penuh dan efektif dengan warga negara lainnya berdasarkan kesam aanhak.Pengaturan mengenai Penyandang disabilitas ini telah memasukkan perspektif Hak Asasi Manusia sebagaimana dinyatakan dalam Pasal 3 UU Penyandang Disabilitas yaitu bahwa pelaksanaan dan pemenuhan Hak Penyandang disabilitas bertujuan untuk (a) Mewujudkan penghormatan, pemajuan, perlindungan dan pemenuhan hak asasi manusia serta kebebasan dasar penyandang disabilitas secara penuh dan setara; (b) Menjamin upaya penghormatan, pemajuan, perlindungan dan pemenuhan hak sebagai martabat yang melekat pada diri Penyandang disabilitas; (c) mewujudkan taraf kehidupan Penyandang Disabilitas yang lebih berkualitas, adil, sejahtera lahir dan batin, mandiri, serta bermartabat; d) Melindungi Penyandangdisabilitas dari penelantaran dan eksploitasi, pelecehan dan segala tindakan diskriminatif serta pelanggaran hak asasi manusia. ${ }^{2}$ Perubahan paradigma tentang Penyandang Disabilitas sebagai bagian Hak Asasi Manusia (HAM) diatur secara spesifik dalam tujuan pelaksanaan dan pemenuhan Hak Penyandang Disabilitas tersebut diatas, menempatkan setiap individu Penyandang Disabilitas mendapatkan jaminan penghormatan, pemajuan, perlindungan dan pemenuhan HAM dari negara. Penyandang Disabilitas didudukkan sebagai subjek yaitu sebagai individu yang memiliki hak dan kewajiban sehingga penyelenggaraan kesejahteraan sosial untuk penyandang disabilitas tidak hanya berupa rehabilitasi sosial dan jaminan sosial namun juga meliputi pemberdayaansosial dan perlindungan sosial. Pemberdayaan dan perlindungan sosial ini ditujukan untuk menguatkan Hak Penyandang Disabilitas untuk menjadi individu yang tangguh dan mandiri melalui pelatihan, pendampingan, peningkatanaksesinformasi, advokasisosial, bantuanhukum dan lain-lain. ${ }^{3}$

Pengembangan bahasa isyarat bagi yang berkebutuhan khusus yaitu Penyandang Disabilitas tuna rungu sangat dibutuhkan dalam pengembangan dan pembinaan bahasa di Indonesia. Kekurangan ini tentunya memberikan hambatan serta menyulitkan Penyandang Disabilitas Tuna Rungu salah satunya dalam menikmati berita maupun hiburan pada siaran televisi.

Undang-UndangNomor 32 Tahun 2002 tentang Penyiaran menjamin bahwa hak memperoleh informasi adalah hak mutlak bagi setiap warga negara tanpa memandang kelompok. Jaminan ini harusnya juga diberikan kepada mereka yang memiliki kemampuan yang berbeda atau kaum disabilitas seperti tuna rungu. Pasal 39 ayat(3) UU Penyiaran No.32 tahun 2002 menyatakan jaminan akan hak informasi dengan ketersediaan penerjamahan. Akan tetapi pasaldalam UU tersebut tidak tegas mewajibkan serta tidak adanya pengaturan sanksi bilamana tidak menerapkannya dengan baik terhadap kepastian pemenuhan secara maksimal bagi kaum Disabilitas dalam menikmati siaran televisi.

Dari latar belakang diatas dapat dirumuskan rumusan masalah yaitu:

1. Pengaturan bagi Penyandang DisabilitasTuna rungu dalam memperoleh informasi.

2. Urgensi perlindungan serta Affirmative Action terkait kepastian dalam pemenuhan hak menikmati acara televisi bagi Penyandang Disabilitas Tuna rugu.

\subsection{MetodePenulisan}

Metode yang digunakan alam penulisan ini adalah metode penulisan Hukum Normatif. Menggunakan pendekatan Perundangundanganya itu mengkaji peraturan perundang- 
undangan yang ada terkait dengan rumusan masalah. Sumber Bahan Hukum yang digunakan berupa bahan hukum Primer, sekunder dan tersier yaitu:

a. Bahan Hukum Primer

Bahan hukum primer dalam penulisan ini terdiri atas:

1. UUD NRI Tahun 1945

2. UUNomor 8 Tahun 2016 tentang Penyandang Disabilitas.

3. UU Nomor.32 Tahun 2002 tentang Penyiaran.

4. UU Nomor 39 Tahun 1999 Tentang Hak Asasi Manusia.

b. BahanHukumSekunder

Bahan Hukum Sekunder yang digunakanberupa literatur-literatur serta artikelartikel yang terkait dengan rumusan masalah

Teknik pengumpulan Bahan Hukum yang akan digunakan dalam penulisan ini dilakukan dengan cara studi kepustakaan. Studi kepustakaan dilakukan untuk mengumpulkan data sekunder melalui pengkajian terhadap peraturan perUndang-Undangan, literatur-literatur, tulisantulisan para pakar hukum

Teknik pengolahanbahanhukum yang digunakanadalah Teknik deskripsi, evaluasi dan argumentasi.

\section{PEMBAHASAN ISI}

2.1 Pengaturan bagi Penyandang Disabilitas dalam memperoleh informasi.

Penyandang disabilitas mempunyai kedudukan yang sama di depan hukum serta mempunyai Hak Asasi Manusia yang sama sebagai Warga Negara. Jaminan yang diberikan kepada Penyandang disabilitas daapat berupa jaminan yang diberikan oleh Undang-Undang agar penyandang disabilitas dapat memperoleh kesempatan serta menikmati hak-haknya secara baik..

Tahun 1997 diundangkanlah UU Nomor 4 Tahun 1997 tentang Penyandang Cacat. Pasal 1 angka 1 UU No. 4 Tahun 1997 menyebutkan bahwa Penyandang cacat adalah setiap orang yang mempunyai kelainan fisik dan/atau mental, yang dapat mengganggu atau merupakan rintangan dan hambatan baginya untuk melakukan secara selayaknya, yang terdiridari :

a. penyandang cacatfisik;

b. penyandang cacat mental;

c. penyandang cacatfisik dan mental.

Pasal 5 nya menyebutkan bahwa setiap penyandang cacat mempunyaihak dan kesempatan yang sama dalam segalaaspekkehidupan dan penghidupan. Setiap penyandang cacat berhak memperoleh :

a. Pendidikan pada semuasatuan, jalur, jenis, dan jenjang pendidikan;

b. Pekerjaan dan penghidupan yang layak sesuai dengan jenis dan derajatkecacatan, pendidikan, dan kemampuannya;

c. Perlakuan yang sama untuk berperan dalam pembangunan dan menikmati hasil-hasilnya;

d. Aksesibilitas dalam rangka kemandiriannya;

e. Rehabilitasi, bantuansosial, dan pemeliharaan taraf kesejahteraansosial; dan

f. Hak yang sama untuk menumbuh kembangkan bakat, kemampu-an, dan kehidupan sosialnya, terutama bagi penyandang cacat anak dalam lingkungan keluarga dan masyarakat( Pasal 6 UU No. 4 Tahun 1997)

Aksesibilitas adalah kemudahan yang disediakan bagi penyandang cacat guna mewujudkan kesamaan kesempatan dalam segala aspek kehidupan dan penghidupan.Setiapp enyandang cacat mempunyaikesamaan kesempatan dalam segala aspek kehidupan dan penghidupan dan pemerintah mempunyai kewajiban untuk mengupaya kanterwujudnya segala hak tersebut.

Pada tahun 2006 disepakatilah KonvensiHak-Hak Penyandang Disabilitas. Konvensi ini disepakati pada tanggal 13 Desember 2006 oleh Majelis Umum Perserikatan Bangsa Bangsa dengan Resolusi 61/106 dan terbuka untuk ditandatangani oleh Negara-negara anggota PBB pada tanggal 30 Maret 2007. Indonesia mengirim delegasi untuk penandatanganan yang dipimpin oleh departemen teknisyaitu DepartemenSosial Republik Indonesia. Pada bagian Pembukaan Konvensihuruf(v) disebutkan bahwa Mengakui 
pentingnya aksesibilitas kepada lingkungan fisik, sosial, ekonomi dan kebudayaanbagi kesehatan dan pendidikan, sertainformasi dan komunikasi, yang memungkinkan penyandang disabilitas untuk menikmati sepenuhnya semuahak-hak asasi manusia dan kebebasan fundamental,.

Pasal 1 Konvensi mengatur tentang tujuan konvensi yaitu untuk memajukan, melindungi dan menjaminpenikmatansecarapenuh dan setarasemuahak-hakasasimanusia dan kebebasan fundamental oleh semuapenyandangdisabilitas, dan untukmeningkatkanpenghormatanatasmartabat yang melekat pada mereka. Penyandangdisabilitas mencakupi mereka yang memiliki-penderitaan fisik, mental, intelektual, atausensorik dalam jangka waktu lama dimana interaksidenganberbagai hambatan dapat menyulitkan partisipasi penuh dan efektifdalam masyarakat berdasarkan kesetaraan dengan yang lainnya.

Pasal 2 Konvensi mengatur mengenaidefinisi untuktujuanKonvensiini, yaitu:

a. "Komunikasi" mencakupi bahasa, tayanganteks, Braille, komunikasi tanda timbul, cetakbesar, multimedia yang dapat diakses seperti juga maupun bentuk-bentuktertulis, audio, plain-language, pembaca-manusia dan bentuk-bentuk, sarana dan format komunikasitambahanmaupunalternatiflainnya, sarana, termasukinformasi dan teknologi komunikasi yang dapat diakses;

b. "Bahasa" mencakup bahasalisan dan bahasaisyaratsertabentuk-bentuk bahasanonlisan yang lain;

c. "Diskriminasi berdasarkan disabilitas" berarti setiap pembedaan, pengecualian, atau pembatasan atas dasar disabilitas yang bermaksud atau berdampak pengurangan atau peniadaan pengakuan, penikmatan dan pelaksanaan, atasdasar kesetaraan dengan manusia lainnya terhadap semua hak-hak asasi manusia dan kebebasan fundamental dalam bidang politik, ekonomi, sosial, kebudayaan, sipil atau lainnya. Hal inimencakupi semua bentuk diskriminasi, termasuk penolakan atas pemberiana komodasi yang patut; d. "Akomodasi yang patut" berartimodifikasi dan penyesuaian yang harus dan sesuai, dengan tidak memberikan beban tambahan yang tidak proporsional atau tidak perlu dalam menghadapi kasuskhusus, guna menjamin penikmatan dan pelaksanaan semuahak-hak asasi manusia dan kebebasan fundamental berdasarkan kesetaraan penyandang disabilitas e. "Desain universal" berarti desain produk, lingkungan, program-dan pelayanan yang dapat digunakan oleh semua orang, semaksimal mungkin, tanpa memertukan suatu adaptasi atau rancangan khusus. "Desain universal” tidak dapat mengesampingkan alat bantu bagi kelompok khusus penyandang disabilitas pada saat diperlukan.

Selanjutnya Pasal 9Konvensi ini mengatur tentang Aksesibilitas para penyandang disabilitas dimana diatur agar penyandang disabilitas mampu hidupsecaramandiri dan berpartisipasi secara penuh dalam semua aspek kehidupan, NegaraNegara Pihak wajib mengambil Iangkah yang tepat untuk menjamin akses bagi penyandang disabilitas, atasdasarkesamaandenganwargalainnya, terhadaplingkunganfisik, transportasi, informasi, dan komunikasi, termasuksistem serta teknologi informasi dan komunikasi, serta akses terhadapfasilitas dan jasapelayanan lain yang terbuka atau tersediauntuk publik, baik di daerahperkotaan maupun pedesaan. LangkahIangkah yang wajib meliputi identifikasi dan penghapusan kendala serta halangan terhadap aksesibilitas, wajib berlaku, inter alia :

(a) Gedung-gedung, jalan-jalan, sarana transportasi, clan fasilitas dalam dan luar ruang Iainnya, termasuksekolah, perumahan, fasilitasmedis, dan tempatkerja;

(b)Informasi, komunikasi, dan layanan Iainnya, termasuk layanan elektronik dan layanan gawat darurat.

Dengan adanya usaha-usaha yang terbilangmasif serta dilakukan secara global, memang seharusnya Indonesia berpatokan pada gerakan ini untuk memperjuangkan hak-hak orang dengan disabilitas agar dapat memperoleh akses khususnya untuk menikmati konten visual seperti televisi. 
Selanjutnya dalam Pasal 30 Konvensi mengatur tentang Partisipasi dalam Kebudayaan, Rekreasi, Hiburan, dan Olah Raga disebutkan bahwa:Negara-Negara Pihak mengakui hak-hak penyandang disabilitas untuk berperan atas dasar kesamaan dengan orang lain dalamkehidupan kebudayaan, dan akan mengambil langkahlangkah yang diperlukan untuk memastikan agar penyandang disabilitas:

(a) Menikmati akses terhadap benda-benda kebudayaan dalam bentuk yang mudah diakses;

(b) Menikmati akses terhadap program televisi, film, teater, dan kegiatan kebudayaan lain dalam bentuk yang mudahdiakses.

(c) Menikma akses ketempat-tempat pertunjukan atau pelayanan budaya, seperti teater, museum, bioskop, perpustakaan, dan jasa pariwisata, dan sejauh memungkinkan, menikrnati akses ke monumen dan tempat yang memilikinilai budaya penting;

Dari Konvensi ini dapat dilihat sudah terdapat pengaturan tentang Hak-Hak Penyandang Disabilitas untuk mendapatkan aksesibilitas yang samadengan orang pada umumnya agar bisahidupmandiri dan mengembangkan kehidupannya termasuk memperoleh hak menikmati akses terhadap program televisi, film, teater, dan kegiatan kebudayaan lain dalam bentuk yang mudah diakses.

Empat tahun kemudian Indonesia telah meratifikasi konvensi tersebut melalui UndangUndang No 19 Tahun 2011 tentang Pengesahan Convention On The Rights Of Persons With Disabilities (Konvensi Mengenai Hak-Hak Penyandang Disabilitas) pada tanggal 18 Oktober 2011. Pada bagian Penjelasan Umum UU tersebut disebutkan bahwa Negara Republik Indonesia yang berdasarkan Pancasila dan UndangUndang Dasar Negara Republik Indonesia Tahun 1945 menghormati dan menjunjung tinggi harkat dan martabat manusia. Hak asasi manusia sebagai hak dasar yang secara kodrati melekat pada diri manusia, bersifat universal dan langgeng, juga dilindungi, dihormati, dan dipertahankan oleh Negara Republik Indonesia, sehingga perlindungan dan pemajuan hak asasimanusia terhadap kelompok rentan khususnya penyandang disabilitas perlu ditingkatkan. Pada tanggal 13 Desember 2006 MajelisUmum Perserikatan Bangsa-Bangsa telah mengeluarkan Resolusi Nomor A/61/106 mengenai Convention on the Rights of Persons with Disabilities (Konvensitentang Hak-Hak Penyandang Disabilitas). Resolusi tersebut memuat hak-hak penyandang disabilitas dan menyatakan akan diambil langkah-langkah untuk menjamin pelaksanaan konvensiini. Pemerintah Indonesia telah menandatangani Convention on the Rights of Persons with Disabilities (Konvensi mengenai Hak-Hak Penyandang Disabilitas) pada tanggal 30 Maret 2007 di New York. Penandatanganan tersebut menunjukan kesungguhan Negara Indonesia untuk menghormati, melindungi, memenuhi, dan memajukan hak-hak penyandang disabilitas, yang pada akhirnya diharapkan dapat memenuhi kesejahteraan para penyandang disabilitas.

Pada Tahun 2016 diundangkanlah UU No. 8 Tahun 2016 Tentang Penyandang Disabilitas. DalamPasal 1 angka 1 disebutkan bahwa Penyandang Disabilitas adalah setiap orang yang mengalami keterbatasan fisik, intelektual, mental, dan/atau sensorik dalam jangka waktu lama yang dalam berinteraksi dengan lingkungan dapat mengalami hambatan dan kesulitan untuk berpartisipasi secara penuh dan efektif dengan warga negara lainnya berdasarkan kesamaan hak. Kemudian dalamAngka 8 nyadiatur juga mengenai Aksesibilitas yaitu kemudahan yang disediakan untuk Penyandang Disabilitas guna mewujudkan Kesamaan Kesempatan. Pasal 2 nya mengatur bahwa Pelaksanaan dan Pemenuhan hak Penyandang Disabilitas berasaskan:

a. Penghormatan terhadap martabat; '

b. otonomi individu;

c. tanpa Diskriminasi;

d. partisipasi penuh;

e. keragaman manusia dan kemanusiaan;

f. Kesamaan Kesempatan;

g. kesetaraan;

h. Aksesibilitas; 
i. kapasitas yang terus berkembang dan identitas anak;

j.inklusif; dan

k. perlakuan khusus dan Pelindungan lebih

Pasal 3 UU No. 8 Tahun 2016 mengatur

bahwa Pelaksanaan dan Pemenuhan hak Penyandang Disabilitas bertujuan:

a. mewujudkan Penghormatan, pemajuan, Pelindungan, dan Pemenuhan hak asasi manusia serta kebebasan dasar Penyandang Disabilitas secara penuh dan setara;

b. menjaminupaya Penghormatan, pemajuan, Pelindungan, dan Pemenuhan hak sebagai martabat yang melekat pada diri Penyandang Disabilitas;

c. mewujudkan taraf kehidupan Penyandang Disabilitas yang lebih berkualitas, adil, sejahtera lahir dan batin, mandiri, serta bermartabat;

d. melindungi Penyandang Disabilitas dari penelantaran dan eksploitasi, pelecehan dan segala tindakan diskriminatif, serta pelanggaran hak asasimanusia; dan

e. memastikan pelaksanaan upaya Penghormatan, pemajuan, Pelindungan, dan Pemenuhan hak Penyandang Disabilitas untuk mengembangkan diri serta mendayagunakan seluruh kemampuan sesuai bakat dan minat yang dimilikinyauntukmenikmati, berperan serta berkontribusi secara optimal, aman, leluasa, dan bermartabat dalam segala aspek kehidupan berbangsa, bernegara, dan bermasyarakat.

Pasal 4 ayat(1) nya menyebutkan bahwa Ragam Penyandang Disabilitas meliputi:

a. Penyandang Disabilitas fisik;

b. Penyandang Disabilitas intelektual;

c. Penyandang Disabilitas mental; dan/atau d. Penyandang Disabilitas sensorik.

Ayat (2) nya menyatakan bahwa Ragam Penyandang Disabilitas sebagaimana dimaksud pada ayat (1) dapat dialami secara tunggal, ganda, atau multi dalam jangka waktu lama yang ditetapkan oleh tenagamedis sesuai dengan ketentuan peraturan perundang-undangan. Pada Bab III diatur mengenai Hak Penyandang Disabilitas. Dalam Pasa 15 ayat (1) disebutkan bahwa Penyandang Disabilitas mempunyai hakhak yaitu: a. hidup;

b. bebasdari stigma;

c. privasi;

d. keadilan dan perlindungan hukum;

e. pendidikan;

f. pekerjaan, kewirausahaan, dan koperasi;

g. kesehatan;

h. politik;

i. keagamaan;

j. keolahragaan;

k. kebudayaan dan pariwisata;

1. kesejahteraan sosial;

m. Aksesibilitas;

n. Pelayanan Publik;

o. Pelindungan dari bencana;

p. habilitasi dan rehabilitasi;

q. Konsesi;

r. pendataan;

s. hidup secara mandiri dan dilibatkan dalam masyarakat;

t. berekspresi, berkomunikasi, dan memperoleh informasi;

u. berpindah tempat dan kewarganegaraan; dan

v.bebasdari tindakan Diskriminasi, penelantaran, penyiksaan, dan eksploitasi.

Pada tulisan ini yang di bahasa dalah Penyandang Disabilitas sensorik yang mengalami keterbatasan pendengaran dan bicara. Dari UU tersebut diatas dapat diketahui bahwa UU telah menjamin hak penyandang disabilitas untuk memperolehi nformasi. Ada 21 macam hak bagi penyandang disabilitas yang diatur dalam UU No. 8 Tahun 2016 pada Bagian Kedua Puluh Hak Berekspresi, Berkomunikasi, dan Memperoleh Informasi yaitu dalam Pasal 24 nya yang meliputi hak:

a. memiliki kebebasan berekspresi dan berpendapat;

b. mendapatkan informasi dan berkomunikasi melalui media yang mudah diakses; dan

c. menggunakan dan memper oleh fasilitas informasi dan komunikasi berupa bahasa isyarat, braille, dan komunikasi augmentatif dalam interaksi resmi.

Pasal 123 nyamengatur juga tentangkewajibanPemerintah dan Pemerintah 
Daerah dalam menjamin hak-hak penyandang disabilitas, disebutkan bahwa ayat (1) Pemerintah dan Pemerintah Daerah wajib menjamin aksesatas informasi untuk Penyandang Disabilitas. Ayat (2) Aksesatas informasi untuk Penyandang Disabilitas sebagaimana dimaksud pada ayat (1) dalam bentuk audio dan visual.

Daripaparandiatasdapatdiketahuibahwa UU telah memberikanjaminan kepada penyandang disabilitas untuk mendapatkan informasi dan berkomunikasi melalui media yang mudah diakses; dan menggunakan dan memperoleh fasilitas informasi dan komunikasi berupa bahasa isyarat, braille, dan komunikasi argmentatif dalam interaksi resmi, serta mewajibkan Pemerintah serta Pemerintah Daerah untuk menjaminnya.

Sebagai Pelaksana dari UU No. 8 Tahun 2016, UU mengamanatkan bahwa diatur dalam bentuk PeraturanPemerintah. Pemerintah berencana membentuk satu Peraturan Pemerintah (PP) "sapujagat" untuk melaksanakan 15 ketentuan PP yang diamanatkan dalam UndangUndang Nomor 8 tahun 2016. Keputusan Pemerintah itu mendapat penolakandari masyarakatpenyandang disabilitas yang berasal dari berbagai organisasi penyandang disabilitas maupun organisasi lain yang aktif dalam advokasi isu disabilitas. Penolakan itu didasarkan kepada argumentasi bahwa PP "sapujagat" merupakan bentuk pelanggaran terhadap UU Penyandang Disabilitas dan prinsip dalam Konvensi Hak-Hak Penyandang Disabilitas (Convention on the Rights of People with Disabilities - CRPD); lemahnya kepemimpinan dalam Pemerintah untuk mengimplementasikan UUPenyandang Disabilitas; sertabentuk penyimpangan dari komitmen implementasi UU Penyandang Disabilitas. Perwakilan Pemerintah dalam kegiatan Konsultasi Nasional yang diselenggarakan di Jogjakarta pada 25-27 Juli 2017, Kementerian Sosial (Kemensos) dan Kementerian Koordinator Pembangunan Masyarakat dan Kebudayaan (KemenkoPMK), menyampaikan bahwa keputusan PP "sapujagat" didasari oleh tiga alasan utama, yaitu Pertama, kebijakan deregulasi yang sedang digariskan oleh Presiden Joko Widodo; Kedua, ketiadaan anggaran yang 70 disediakan oleh Kemeterian/Lembaga (K/L) untuk pembentukan PP selaindari Kementerian Sosial; dan Ketiga, percepatan proses pembentukan PP sehingga target pengesahan pada 2018 dapat tercapai. Ketiga argumentasi ini menggambarkan pemahaman dan keberpihakan yang lemah dari Pemerintah terhadap implementasi UU Penyandang Disabilitas. Pemerintah hanya fokus bagaimana menggugurkan kewajiban yang diberikan UU, yaitu memenuhi amanat pembentukan peraturan pelaksanaan paling lambat 3 tahunsetelahUU disahkan, yang jatuh pada April 2018. Dalamkondisiitu, Pemerintah seakan lupa terhadap komitmen yang sudah dibangun pasca pengesahan UU Penyandang Disabilitas, yaitu meletakan disabilitas sebagai isu multisektor dan menempatkannya sebagai isu Hak Asasi Manusia (HAM).

Penyederahaan 15 ketentuan PP menjadi 1 PP "sapu jagat" menunjukan bahwa Pemerintah masih memandang disabilitas hanya sebagai isu rehabilitasi sosial semata, yang dalam implementasinya hanya ditangani oleh Kementerian Sosial. Hal itu jelas tidak selaras dengan semangat pembentukan UU PenyandangDisabilitas yang dengan tegas dalam pengaturannya sudah memasukan berbagai sektor pemerintahan. Selain itu, carapandang Pemerintah itu bertentangan dengan janji Presiden pada masa kampanye lalu, yang kemudian dituangkan dalam Piagam Soeharso yang di tandatangan diatas materai oleh Joko Widodo sendiri.

Pelibatan kelompok masyarakat disabilitas ini juga dapat menjadi kunci percepatan pembentukan PP. Minimnya pemahaman substansi mengenai isu disabilitas pada Kementerian/ Lembaga $(\mathrm{K} / \mathrm{L})$ dapat didukung oleh pengetahuan dan pengalaman kelompok penyandang disabilitas. Bahkan, di berbagai kesempatan dalam berkolaborasi dengan Pemerintah atau pemerintah daerah, pelibatan kelompok masyarakat disabilitas juga mampu mendukung pendanaan yang dibutuhkan. Dengan kolaborasi yang baikantara masyarakat penyandang disabilitas dan Pemerintah/pemerintah daerah maka diharapkan mampu menghasilkan berbagai PP yang tepat guna. 
Terkait dengan pembentukan PP implementasi UU PenyandangDisabilitas, masyarakat penyandang disabilitas mengharapkan Pemerintah untuk meninjau ulang keputusannya untuk menyusun PP "sapu jagat" dan terus mengupayakan agar PP dibentuk secara terpisah, serta dibentuk oleh masing-masing $\mathrm{K} / \mathrm{L}$ sesuai dengan tugas dan fungsinya. Dalam hal pembentukannya, masyarakat penyandang disabilitas siap untuk berkolaborasi dengan Pemerintah, terutama untuk memberikan pemahaman atau urgensi dari masingmasing PP, sampai berkontribusi dalam penyusunan draft rancangan PP ataukajian-kajian yang mendukung. ${ }^{4}$

Jika dilihat dalam pelaksanaan hak untuk memperoleh Informasi yang sama bagi kaum disabilitas tuna rungu hal ini terkait dengan hak untuk menikmati acara televisi. Hal ini tentuakan terkait dengan UU Penyiaran yaitu UndangUndang No. 32 Tahun 2002 tentangPenyiaran. Pasal 2 UU Penyiaran mengatur tentangAsas, tujuan, Fungsi, dan Arah Penyiaran yang menyatakan bahwa Penyiaran diselenggarakan berdasarkan Pancasila dan Undang-Undang Dasar Negara Republik Indonesia Tahun 1945 dengan asas manfaat, adil dan merata, kepastian hukum, keamanan, keberagaman, kemitraan, etika, kemandirian, kebebasan, dan tanggungjawab. Sehingga jika dilihat dari ketentuan tersebut dapat diketahui bahwa penyiaran berasaskan keadilan dan merata bagi semua orang termasuk kaum disabilitas tuna rungu. Pasal 39 ayat (3) menyatakan bahwa Bahasa isyarat dapat digunakan dalam mata acara tertentu untuk khalayak tuna rungu. UU Penyiaran didalamnya belum secara tegas mengatur mengenai kewajiban stasiun televise untuk menyediakan akses untuk kaum disabilitas tuna rungu untuk menikmati semua acara di televisi. Tentu hal ini bisa dianalisis bahwa UU Penyiaran diundangkan lebih dahulu dari UU Penyandang Disabilitas yang terbaru sehingga sekiranya belum mengadopsi semangat untuk memberikan hak yang sama bagi kaum disabilitas tuna rungu untuk memperoleh hak yang sama dalam memperoleh informasi terutama dari acara televise yang ada.
2.2. Urgensi perlindungan serta Affirmative Action terkait kepastian dalam pemenuhan hak menikmati acara televisi bagi Penyandang Disabilitas.

Seperti uraian diatas kaum disabilitas tuna rungu merupakan pihak yang seharusnya juga dapat menikmati acara televisi sebagai salah satu akses bagi kaum disabilitas tuna rungu untuk memperoleh informasi. Dimana Televisi merupakan media yang sangat cepat menyebarkan informasi kepada khalayak serta merupakan media yang memadukan antara suara gerak yang melibatkan indera pendengaran dan pengelihatan sehingga disamping memberikan informasi juga dapat memberikan hiburan kepada penikmatnya. Di Indonesia, setiap tahun setidaknya ada sebanyak 5.000 bayi yang lahir dalam keadaan tuli. Jumlah penderita tuli dan bisu itu angkanya tidak pernah berkurang. Malah, akan cenderung untuk terus selalu bertambah, seiring dengan pertambahan jumlah penduduk. ${ }^{5}$ Jumlah penduduk Indonesia tahun 2015 berdasarkan proyeksi Badan Pusat Statistik (BPS), yakni 255.461.700 jiwa, maka berarti ada sekitar 10.729.391 penduduk di Indonesia yang terbatasi kehidupannya karena ketulian dan gangguan pendengaran. ${ }^{6}$

Dalam tulisan yang dimuat oleh kaum disabilitas tuna rungu disampaikan bahwa berusaha untuk pemerintah membuka mata dan memenuhi hak-hak Tuli termasuk pengakuan Bahasa Isyarat Indonesia (BISINDO) sebagai bahasa Isyarat resmi untuk kaum Tuli. Hal ini dilakukan karena demi para sahabatnya yang sama-sama Tuli mempunyai banyak hambatan dan diskriminasi berbagai bentuk yang ada di setiap kehidupan sehari-hari dan karena merasa bosan tidak ada akses Tuli seperti yang diinginkan maka dari itu ada keinginan "memberontak" dan ingin situasi Indonesia berubah total agar kaum Tuli Indonesia dapat akses Tuli yang layak dan memadai, adanya dukungan masyarakat terhadap hak-hak Tuli. Saya sendiri tidak bisa mendengar kadang-kadang merasa iri dengan teman-teman saya yang bisa mendengar, karena mereka bisa menikmati TV nasional, informasi, konser musik, dan banyak sekali mudah sekali didapatkan melalui suara. Saya 
tidak bisa menikmati TV nasional, informasi, konsermusik! Semuanya karena tidak ada akses yang layak untuk Tuli! Barangkali jika tidak ada akses Tuli di TV mana mungkin saya bisa menikmati padahal saya jelas-jelas tidak bisa mendengar. Hal ini membuat saya lebih condong menonton film Barat/ Hollywood dengan nyaman, karenaapa? Film Barat menggunakan Bahasa Inggris atau bahasa asing lainnya diterjemahkan ke Bahasa Indonesia melalui subtitles Bahasa Indonesia. Saya ingin membanggakan film Indonesia tapikah? Film Indonesia tidak menyediakan subtitles Bahasa Indonesia, karena film Indonesia yang menggunakan Bahasa Indonesia sehingga tidak perlu menyediakan subtitles seperti film Barat dan cukup didengar. Tapi itu sama sekali tidak memperhatikan kami Tuli tidak bisa mendengar. Kadangkala Tuli sering bertanya kepada orang dengar,'Itu ngomong apa?" terusmenerus malah orang dengar kadang bilang tunggu sampai selesai barujawab atau malah malas menjawab karena bosan menjawab hal yang sama. ${ }^{7}$ Hal ini menunjukkan bahwa tersedianya akses untuk memperoleh hak yang sama dalam menikmati acara televisi merupakan hal yang mendesak dan sangat diperlukan oleh kaum disabilitas tuna rungu untuk memperoleh informasi dan hiburan. Dimana affirmative action sangat diperlukan untuk mengatur hak-hak kaum disabilitas untuk memperoleh hak yang sama dalam menikmati acara televisi.

Dari hasil observasi yang dilakukan didapatkan beberapa siaran televisi yang sudah menggunakan Bahasa isyarat dapat dilihat baru siaran berita tertentu saja yang memberikan akses kepada kaum disabilitas tuna rungu untuk mendapatkan informasi. Siaran televisi tersebut antara lain :Fokus ( Indosiar ), Indonesia Pagi/ Siang/dan Malam ( TVRI ), I News Siang ( I Newa TV), Top News ( Metro ), Redaksi ( Trans 7 ). Sedangkan dapat diketahui bahwabukan saja siaran berita yang di butuhkan oleh kaum disabilitas tuna rungu untuk mendapatkan informasi serta hiburan. Sehingga sangat urgen untuk memberikan pengaturan yang lebih menjamin pemenuhan hak menikmati acara televisibagikaumdisabilitastuna rungu dengan menentukan suatu Affirmative Action yang mewajibkan bagi stasiun TV untuk menyertakan Bahasa Isyarat dalam setiap siarannya.

\section{KESIMPULAN DAN SARAN}

\subsection{Kesimpulan}

1. Tahun 1997 diundangkanlah UU Nomor 4 Tahun 1997 tentang Penyandang Cacat. Pasal 5 nya menyebutkan bahwa setiap penyandang cacat mempunyai hak dan kesempatan yang sama dalam segala aspek kehidupan dan penghidupan. Pada tahun 2006 disepakatilah Konvensi Hak-Hak Penyandang Disabilitas. Konvensi ini disepakati pada tanggal 13 Desember 2006 oleh Majelis Umum Perserikatan Bangsa Bangsa dengan Resolusi 61/106 dan terbuka untuk ditandatangani oleh Negara-negara anggota PBB pada tanggal 30 Maret 2007. Pada bagian Pembukaan Konvensihuruf(v) disebutkan bahwa Mengakui pentingnya aksesibilitas kepada Iingkungan fisik, sosial, ekonomi dan kebudayaan bagi kesehatan dan pendidikan, serta informasi dan komunikasi, yang memungkinkan penyandang disabilitas untuk menikmati sepenuhnya semua hak-hak asasi manusia dan kebebasan fundamental,.Empat tahun kemudian Indonesia telah meratifikasi konvensi tersebut melalui Undang-Undang No 19 Tahun 2011 tentang Pengesahan Convention On The Rights Of Persons With Disabilities (Konvensi Mengenai Hak-Hak Penyandang Disabilitas) pada tanggal 18 Oktober 2011. Pada Tahun 2016 diundangkanlah UU No. 8 Tahun 2016 Tentang Penyandang Disabilitas. Dari UU tersebut diatas dapat diketahui bahwa UU telah menjamin hak penyandang disabilitas untuk memperoleh informasi. UU telah memberikan jaminan kepada penyandang disabilitas untuk mendapatkan informasi dan berkomunikasi melalui media yang mudahdiakses; dan menggunakan dan memperoleh fasilitas informasi dan komunikasi berupa bahasa isyarat, braille, dan komunikasi augmentatif dalam interaksi resmi, serta mewajibkan 
Pemerintah serta Pemerintah Daerah utk menjaminnya. UUPenyiaran didalamnya belum secara tegas mengatur mengenai kewajiban stasiun televise untuk menyediakan akses untuk kaum disabilitas tuna rungu untuk menikmati semua acara di televisi.

2.Beberapa siaran televisi yang sudah menggunakan Bahasa isyarat dapat dilihat baru siaran berita tertentu saja yang memberikan akses kepada kaum disabilitas tuna rungu untuk mendapatkan informasi. Sedangkan dapat diketahui bahwa bukan saja siaran berita yang di butuhkan oleh kaum disabilitas tuna rungu untuk mendapatkan informasi serta hiburan. Sehingga sangat urgen untuk memberikan pengaturan yang lebih menjamin pemenuhan hak menikmati acara televisi bagi kaum disabilitas tuna rungu dengan menentukan suatu Affirmative Action yang mewajibkan bagi stasiun TV untuk menyertakan Bahasa Isyarat dalam setiap siarannya.

\subsection{Saran}

Mengadakan perubahan terhadap UU Penyiaran yang di dalamnya memuat suatu aturan yang mewajibkan stasiun televisi menyediakan akses bagi kaum disabilitas tuna rungu dalamsetiap acara televisi yang ditayangkan.

\section{DAFTAR PUSTAKA}

Muhammad Joni Yulianto, 2014, HakHakPenyandangdisabilitasdalamBuku Panduan BantuanHukumIndonesia :Pedoman Anda Memahami dan MenyelesaikanMasalahHukum, Jakarta, Yayasan Obor Indonesia.

FajriNursyamsi, 2017, MeninjauKembali PP "Sapu Jagat" Implementasi UU $P$ e $n y a n d a n g D i s a b i l i t a s$, www.hukumonline.com/.../meninjau-kembali-pps a p u - jag a t - i m p l e m e n t a s i - u u penyandangdisabilitas, diaksestanggal 12 Juni 2018

Medan Bisnisdaily, 2018, "SetiapTahun Ada 5000 bayilahirDalamKeadaan Tuli di Indonesia", http:/ /www.mdn.biz.id/o/24706/, diaksestanggal 12 Juni 2018

Rakanurmujahid, 2017, “ SebuahSepucuk Surat UntukPemerintahTerhadapHak-HakDifabel Tuli di Indonesia”, hhtps:// rakanurmujahid.wordpress.com/2017/03/02.

RMOL.co, 2017, "Lebihdari 10 Juta Warga Indonesia Tuli, Kenapa?", https://kesehatan.rmol.co/read,

Shidarta, 2014, Affirmative Action SebagaibentukDiskriminasiPositif, businesslaw.binus.ac.id/2014/.../affirmative-actionsebagai-bentuk-diskriminasi-positi,

\section{Undang-Undang}

Undang-Undang Dasar Negara Republik Indonesia Tahun 1945

Undang-Undang No. 4 Tahun1997 tentangPenyandangCacat

Undang-Undang No. 39 Tahun 1999 TentangHakAsasiManusia.

Undang-Undang No.32 Tahun 2002 tentangPenyiaran.

Undang-Undang No.19 Tahun 2011 tentangPengesahanConvention On The Rights Of Persons With Disabilities

Undang-UndangNomor 8 Tahun 2016 tentangPenyandangDisabilitas.

UU Nomor 39 Tahun 1999 TentangHakAsasiManusia.

\section{(Footnotes)}

${ }^{1}$ Shidarta, 2014, Affirmative Action Sebagai bentuk Diskriminasi Positif, business-law.binus.ac.id/ 2014/.../affirmative-action-sebagai-bentukdiskriminasi-positi, diakses tgl 12 Juni 2018

${ }^{2}$ Lihat Undang-Undang Nomor 8 Tahun 2016 tentang Penyandang disabilitas.

${ }^{3}$ Muhammad Joni Yulianto, 2014, Hak-Hak Penyandang disabilitas dalam Buku Panduan Bantuan Hukum Indonesia : Pedoman Anda Memahami dan Menyelesaikan Masalah Hukum, Jakarta, Yayasan Obor Indonesia, h. 254-256.

${ }^{4}$ Fajri Nursyamsi, 2017, Meninjau Kembali PP "Sapu Jagat" Implementasi UU Penyandang Disabilitas, www.hukumonline.com/.../meninjaukembali-pp-sapu-jagat-implementasi-uupenyandangdisabilitas, diakses tanggal 12 Juni 2018

${ }^{5}$ Medan Bisnisdaily, 2018, "Setiap Tahun Ada 5000 bayi lahir Dalam Keadaan Tuli di Indonesia“, http:// www.mdn.biz.id/o/24706/, diakses tanggal 12 Juni 2018

${ }^{6}$ RMOL.co, 2017, “Lebih dari 10 Juta Warga Indonesia Tuli, Kenapa?”, https://kesehatan.rmol.co/read/ , diakses tanggal 18 Juni 2018

${ }^{7}$ Rakanurmujahid, 2017, “ Sebuah Sepucuk Surat Untuk Pemerintah Terhadap Hak-Hak Difabel Tuli di Indonesia", hhtps:// rakanurmujahid.wordpress.com/2017/03/02, diakses tanggal 18 Juli 2018. 